\title{
唾石中のシュウ酸とカルシウム量
}

\author{
大森恒柇原鋭郎岡部京平 \\ 稲 垣幸司山田史 郎* 中静正 \\ 愛知学院大学歯学部歯周病学教室 \\ （主任 : 中静 正教授） \\ 愛知医科大学付属病院歯科口腔外科* \\ （主任：山田史郎教授） \\ (昭和 60 年 12 月 16 日受付)
}

\section{Oxalic Acid and Calcium Levels in Salivary Stone}

\author{
Hisashi OMORI, Toshiro SAKAKIBARA, Kyohei OKABE, \\ Khoji INAGAKI, Shiro YAMADA* and Tadashi NAKASHIZUKA \\ Department of Periodontology, School of Dentistry, Aichi-Gakuin University. \\ (Chief : Prof. Tadashi NAKASHIZUKA) \\ *Department of Oral and Maxillofacial Surgery, Aichi Medical University.
}

(Chief : Prof. Shiro YAMADA)

The role of oxalic acid in salivary stone formation has not been established yet. This study was performed to determine the amount of oxalic acid and calcium in salivary stone.

Oxalic acid level in salivary stone was fractionated by high-performance liquid chromatography (HPLC) using a two column switing system and determined spectrophotomerically by converting it into 2-nitrophenylhydrazine, a method developed by Horikawa et al.. The minimal detectable amount of oxalic acid was $0.2 \mathrm{n} \mathrm{mol}$, and the recovery was $92 \%$ in this system.
Samples were collected and mixed with $0.5 \mathrm{~m} l$ of $1.0 \mathrm{~N} \mathrm{HCl}$ and the mixture was allowed to stand for one hour. Two $\mathrm{m} l$ of $\mathrm{H}_{2} \mathrm{O}$ was added to the reaction mixture and was then filtered through an ultrafiltration menbrane (Immersible $\mathrm{CX}-10 \circledR$ ). The filtrate was then injected onto the HPLC system.

Oxalic acid and calcium levels in salivary stone were $7.25 \pm 3.63 \mathrm{n} \mathrm{mol} /$ dry weight $\mathrm{mg} \pm$ S.D. and $264.7 \pm 58.4 \mu \mathrm{g} / \mathrm{dry}$ weight $\mathrm{mg}$, respectively.

It was concluded from these results that oxalic acid was closely related to the formation of salivary stone.

Key words : salivary stone, oxalic acid, calcium, high-performance liquid chromatography

要旨 : 唾石形成におけるシュウ酸の役割を明らかにする目的で, 唾石症患者から採取した唾石中のシュウ酸量とカル シウム量を測定した。

シュウ酸量の測定は, Horikawa らが開発した高速液体クロマトグラフィーを用いる測定法により測定した。

唾石中のショウ酸量は $7.25 \pm 3.63 \mathrm{n} \mathrm{mol} / \mathrm{dry}$ weight $\mathrm{mg}$ で, カルシウム量は $264.7 \pm 58.4 \mu \mathrm{g} / \mathrm{dry}$ weight mg で あった。この結果から, 唾石の形成にシュウ酸が関与していることが示唆された。

索引用語 : 唾石, シュウ酸, カルシウム, 高速液体クロマトグラフィー 


\section{緒言}

唾石症は, 唾液腺体または導管内に唾石を生ずる疾患 である。臨床的には唾液腺の腫脹を呈することが多く, 唾液の流出障害が強いと, とくに食物攝取時に唾液腺が 腫脹し, 唾液仙痛を生じる。唾石の化学的組成は無機質 が大部分を占め, その主体はリン酸カルシウムと炭酸カ ルシウムである。有機質としてムコ多糖類, 尿酸, 脂質 などを含んでいる11。しかしながら，その形成機序や組 成については，諸説がありいまだ不明な点が多い。

生体内において, 炭水化物やタンパク質の終末代謝産 物としてシュウ酸は尿中に排泄され, 尿中のカルシウム と結合してシュウ酸カルシウムを形成し，これが尿路結 石の原因となると考えられている22。しかしながら，こ のようなシュウ酸と唾石との関係についての報告は見当 らない。

そこで, 我々は唾石中のシュウ酸量とカルシウム量を 測定したので報告する。

\section{実験の試料と方法}

\section{1. 試料の採取と処理}

試料の唾石は, 愛知医科大学附属病院歯科口腔外科外 来を訪ずれた患者のうち, 唾石症と診断された患者 5 名 より外科手術によって採取されたものである。

試料の唾石は粉砕し, その $20 \mathrm{mg}$ に対して $0.5 \mathrm{ml} 1.0$ $\mathrm{N} \mathrm{HCl}$ を加え 1 時間放置した後, $2.0 \mathrm{ml}$ の $\mathrm{H}_{2} \mathrm{O}$ を加え, 限外濾過膜である Immersible CX-10®にて濾過した。 この濾過液を $2 つ に$ 分け, 一つはシュウ酸測定用被検液 とし, 他は濾過液 $20 \mu l$ に対して $980 \mu l$ の 100 ppm ラ ンタン $1 \mathrm{~N} \mathrm{HCl}$ を加えたものをカルシウム測定用被検液 とした。

\section{2. シュウ酸量測定}

シュウ酸量の測定は, Horikawa $ら^{3,4)}$ の高速液体ク口 マトグラフィーを用いる定量法により分離定量を行っ た。

3. カルシウム量測定

カルシウム量は, 原子吸光法 (日立製, 180-60 型) により測定した。

\section{実験成績}

各被検者における唾石中のシュウ酸量とカルシウム量 およびそれらの平均值と標準偏差は Table 1 に示す通り である。

シュウ酸量は, 平均 $7.25 \pm 3.63 \mathrm{n} \mathrm{mol} / \mathrm{dry}$ weight $\mathrm{mg}$, カルシウム量は, 平均 $264.7 \pm 58.4 \mu \mathrm{g} / \mathrm{dry}$ weight mg であった。

\section{考察}

シュウ酸は生体内に打いて炭水化物やタンパク質が, いろいろな分解経路によって分解されて形成され, 尿中 に排泄される。排泄されたシュウ酸は, 尿中のカルシウ ムと結合してシュウ酸カルシウムを形成し, これが尿路 結石の原因となると考えられている2)。そのようなシュ ウ酸カルシウム結晶は, 腎, 軟骨, 心䇟, 骨髄, リンパ 節，脾および血管壁など生体内のいたるところで見出さ れている5)。

シュウ酸の測定法について, 共同研究者の榊原がいろ いろな測定法を検討した結果, Horikawa らによって開 発されたカラムスイッチング法とカルボン酸に特異的な 呈色反応を組み合せた高速液体クロマトグラフィーを用 いる分離定量法は, シュウ酸量が $0.5 \sim 250 \mathrm{n} \mathrm{mol}$ の範囲 で直線関係が得られ, 回収率も約 $92 \%$ と優れた方法で あると報告していることから ${ }^{6)}$ ，この方法により測定し

Table 1 Oxalic acid and calcium contents in salivary stone

\begin{tabular}{|c|c|c|c|}
\hline No. & $\begin{array}{l}\text { Collection Volume } \\
\text { (dry weight mg) }\end{array}$ & $\begin{array}{l}\text { Oxalic Acid Content } \\
\text { (n mol/dry weight } \mathrm{mg} \text { ) }\end{array}$ & $\begin{array}{c}\text { Ca Content } \\
\text { ( } \mu \mathrm{g} / \text { dry weight } \mathrm{mg})\end{array}$ \\
\hline 1 & 30.0 & 4.56 & 330.8 \\
\hline 2 & 58.7 & 7.73 & 173.4 \\
\hline 3 & 476.2 & 13.18 & 280.8 \\
\hline 4 & 385.2 & 6.49 & 251.0 \\
\hline 5 & 195.5 & 4.18 & 287.3 \\
\hline & Mean \pm S.D. & $7.25 \pm 3.63$ & $264.7 \pm 58.4$ \\
\hline
\end{tabular}


た。

唾石中のシュウ酸量について, 報告が見当らないので 比較することができないが，我々の実験結果において， $7.25 \pm 3.63 \mathrm{n} \mathrm{mol} /$ dry weight $\mathrm{mg}$ であり,カルシウム量 は, 264.7 $\pm 58.4 \mu \mathrm{g} / \mathrm{dry}$ weight mg であった。榊原は, 全唾液, プラーク, 軟歯石および歯石中のシュウ酸量と カルシウム量を測定しており，シュウ酸量は，全唾液が $2.76 \pm 0.45 \mathrm{n} \mathrm{mol} / \mathrm{m} l$ of filtered saliva，プラークが 0.58 $\pm 0.30 \mathrm{n} \mathrm{mol} /$ wet weight $\mathrm{mg}$, 軟歯石が $1.51 \pm 0.83$ $\mathrm{n} \mathrm{mol} /$ wet weight $\mathrm{mg}$, 歯石が $4.66 \pm 3.12 \mathrm{n} \mathrm{mol} /$ wet weight mg であり, またカルシウム量は, 全唾液が $60.6 \pm 9.0 \mu \mathrm{g} / \mathrm{m} l$ of filtered saliva, プラークが $11.8 \pm$ $6.2 \mu \mathrm{g} /$ wet weight $\mathrm{mg}$, 軟歯石が $137.5 \pm 28.8 \mu \mathrm{g} / \mathrm{wet}$ weight mg, 唾石が $220.1 \pm 96.8 \mu \mathrm{g} /$ wet weight $\mathrm{mg}$ で あり，シュウ酸量とカルシウム量との間には危険率 $1 \%$ 以内で有意な相関性が認められたと報告している6)。榊 原の報告は湿重量当りであり, 我々のは乾燥重量当りで あるので単純に比較することはできないが，口腔内で形 成される結石である歯石と比較しても，唾石中のシュウ 酸量は約 1.5 倍以上含まれていた。それに対してカルシ ウム量はほほほ同じような量であった。

唾石の化学的な組成は, $80 \%$ が無機質であり，その 70 \%がリン酸カルシウムで， $10 \%$ が炭酸カルシウムであ り, 有機質としてムコ多糖類, 尿酸, 脂質であるといわ れている。

唾石の形成について石川によれば，唾液の化学的性状 の変化, 唾液の停滞, 局所の炎症などが原因となって, 無機質が析出して形成されると述べている1)。

以上のことを考え合せると，睡液中に含まれているシ ユウ酸とカルシウムが何らかの原因によって析出して, 唾液腺中でシュウ酸カルシウム結晶が形成され, 唾石形 成の一原因となりらることが推察される。

\section{結 論}

高速液体クロマトグラフィーを用いるシュウ酸分離測 定法により唾石中のシュウ酸量と原子吸光法によりカル シウム量を測定した。

その結果, 唾石中のシュウ酸量は平均 $7.25 \pm 3.68$ $\mathrm{n} \mathrm{mol} / \mathrm{dry}$ weight $\mathrm{mg}$ であり, カルシウム量は平均 $264.7 \pm 58.4 \mu \mathrm{g} / \mathrm{dry}$ weight $\mathrm{mg}$ であり, 唾石の形成に シュウ酸が関与していることが推察された。

\section{文献}

1）石川梧郎 (監修): 口腔病理学 II, 永末書店, 京都, 1984, 426-429.

2) Hodgkinson, A. : Determination of oxalic acid in biological material. Clin. Chem., $16: 547-$ $557,1970$.

3) Horikawa, R. and Tanimura, T. : Spectrophotometric determination of carboxylic acids with 2-nitrophenylhydrazine in aqueous solution. Anal. Lett., 15 : 1629-1642, 1982.

4) 才木良則, 吉田真吾, 堀川力三, 谷村急徳 : オル トニトロフェニルヒドラジド発色反応を用いる液 体クロマトグラフィーによる尿中シュウ酸の定 量. 日本薬学会, 第 103 年会講演要 旨 集, 123 , 1983.

5）紫田 進 : 病態生化学, 金芳堂, 京都, 1979, 140141.

6）榊原鋭郎：歯周病とシュウ酸との関係, 日歯周誌, 27 : 518-526, 1985. 